\title{
A anamorfose na composição de Las meninas de Picasso
}




\section{Resumo}

A leitura que Picasso faz de Las meninas passa por um processo de distorção evidente nas 58 telas que o pintor malaguenho compõe inspirando-se no referido quadro de Velázquez. Essas dirtorções, típicas de um processo anamorfósico, tal qual o entende Jacques Lacan, acentuam-se - é o que pretendemos assinalar neste texto - à medida que Picasso se afasta do quadro do mestre e deixa transparecer as marcas de sua enunciação.

\section{Palavras-chave}

Picasso, Velázquez, anamorfose

\section{Abstract}

The reading that Picasso has done of Velázquez's portrait Las meninas demonstrates evidences of a process of distortions which is shown on the fifty-eight canvases that he had painted inspired in the abovementioned masterpiece. This text intends to mark that those distortions, which - according to Jacques Lacan - are typical from an anamorphics process, went deeper as Picasso moved away from the original and allowed his own enunciation to come out.

\section{Key words}

Picasso, Velázquez, anamorphosis 
U I - u não procuro, acho" Esta frase célebre, atribuída a Pablo - Picasso, de alguma forma parece ilustrar o longo e, de certa forma, tumultuado percurso em que o pintor

malaguenho se envolveu ao deter o seu olhar no famoso quadro de Diego Velázquez, Las meninas - talvez desta com maior afinco do que de outras vezes que contemplou o quadro do mestre.

A leitura pictural que Picasso faz de Las meninas compreende nada menos do que 58 outros quadros, pintados em pouco mais de quatro meses, em Cannes, no período de agosto a dezembro, correspondente ao outono/inverno de 1957 . Não nos cabe neste momento' adentrar por todos os meandros a que a leitura picassiana nos remete. Em El secreto de las meninas de Picasso, Josep Palau i Fabre ( 1982) reproduz e comenta cada um desses 58 quadros, trazendo informações muito valiosas para quem se interessa por uma visão mais abrangente da referida obra - algumas destas informações, como a referência ao balé Las meninas ${ }^{2}$, a que Picasso teria assistido em 1917, nos serão de grande valia, como teremos oportunidade de mostrar neste trabalho.

1. Este texto foi inicialmente apresentado, em forma de comunicação, no IV Congresso Internacional da Federação Latino-americana de Semiótica, realizado em La Coruna, Espanha, de 27 de setembro a 2 de outubro de 1999.

2. Esta peça, inspirada na obra homônima de Velázquez, foi encenada pelo Ballets Russes, companhia liderada por Serguei Diaghilev, que na época exercia grande influência no mundo da moda, da dança, da música, dos cenários e figurinos teatrais de Paris. 
Antes porém de tratar das anamorfoses, objeto que pretendemos enfatizar em nosso presente estudo, convém se deter um pouco no quadro de Velázquez para destacar alguns de seus elementos que entendemos terem sido relevantes para a leitura picassiana.

Num primeiro olhar, em se tratando de uma reprodução como a de que dispomos de Las meninas (Figura I), o quadro não chega propriamente a impressionar. Retrata uma cena que poderíamos chamar de doméstica: em seu ateliê, o pintor trabalha contando com a presença da princesa Margarita, suas damas de companhia, serviçais, anões e até um cão. Nada mais corriqueiro, pode-se imaginar, no diaa-dia de um palácio real, nãó fosse a pompa das vestimentas.

A figura do pintor, envergando seu traje de nobre cavaleiro, é instigante. $\mathrm{O}$ que ele estaria pintando vestido assim de maneira tão solene? A tela que trabalha está voltada para o outro lado, e vemos apenas a sua parte posterior. Mas podemos notar, comparando-a com o tamanho do cavalete e com a altura do pintor, que ela é bastante grande e ocupa um espaço privilegiado no quadro que nos é dado ver.

Também nos parece estranho, reparando melhor, que uma área escura predomine em quase três quartos da tela, fazendo com que os objetos do ateliê, particularmente os quadros dependurados na parede ao fundo, fiquem na penumbra, praticamente irreconhecíveis.

Mas eis que em meio à semi-escuridão descobrimos uma fonte de luz que invade o local através de uma porta que se abre ao fundo. O personagem que a abriu ainda está lá, nos degraus que dão acesso ao ateliê. Está estático, como se descobrisse, de repente, o pintor trabalhando e não quisesse fazer um movimento mais brusco ou qualquer ruído a fim de não atrapalhar o artista.

Desviando um pouco o olhar à esquerda, a partir desta porta, nossa atenção se detém em um dos quadros da parede, iluminado, ao que parece, pela luz que adentra pela porta que se abriu. Como esse quadro está bem mais nítido do que os outros, distingue-se perfeitamente o retrato de um casal, que pode ser facilmente identificado: trata-se do rei Filipe IV e sua esposa, a rainha Mariana - os pais da princesinha que está ali no ateliê. 


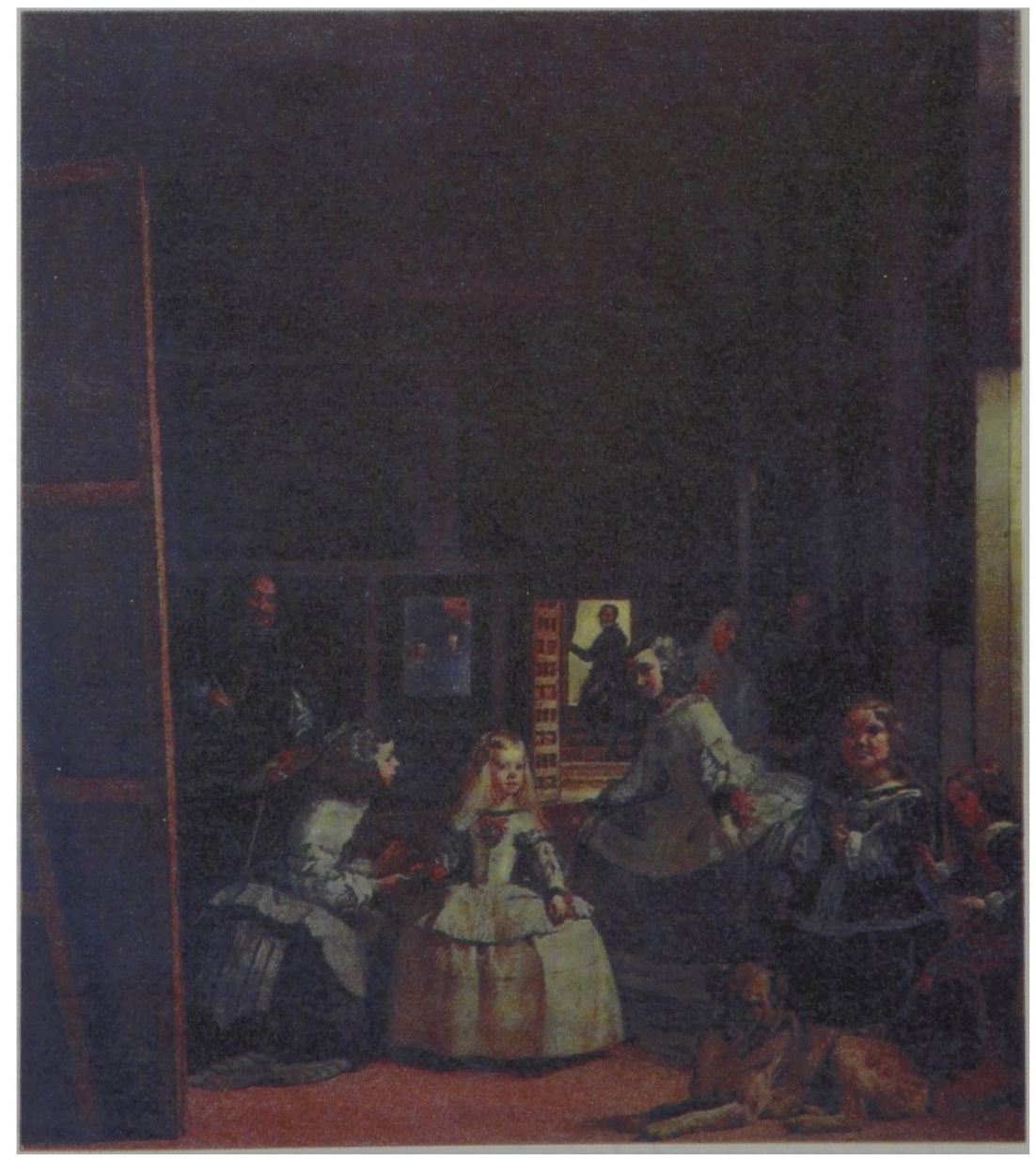

Figura I - Velázquez, Las meninas, óleo sobre tela, 1656. 
Este percurso arbitrário de nosso olhar logo nos remete de volta à figura do pintor, que está com o pincel suspenso no ar, pronto para completar mais um traço na tela, e olha fixamente para seu modelo. Isso nos desconcerta, o modelo está fora do campo do quadro que nos é dado ver - não podemos saber de quem ou de que se trata; mas podemos, isto sim, nos colocar em seu lugar. E é emocionante: situando-se nesta posição, o olhar do pintor incide diretamente em nossa direção.

Para fugir deste olhar, desviamos o nosso para a frente, nos deparamos com o quadro do rei e descobrimos, maravilhados, que ele esteve ali, onde agora estamos. E, curioso, se em vez de nós fossem o rei e a rainha que ali de novo se colocassem, eles teriam o seu retrato bem a sua frente, como se um espelho os refletisse e eles pudessem se contemplar.

Pensando no espelho, voltamos a examinar, agora com mais cuidado, o retrato do rei e da rainha pendurado na parede. Percebemos que a luz que vem da porta ao fundo não é a que o ilumina. Há uma janela lateral, que talvez possa melhor iluminá-lo; mas, mesmo assim, o destaque que esse quadro tem em relação a sua moldura é muito acentuado, e o quadro brilha por igual, como se uma luz direta, que não poderia, nas condições apresentadas, vir de parte alguma, incidisse sobre ele. E isso só seria possível se ele fosse, não uma tela, mas um espelho, que reflete uma luz que está em outro lugar.

Se isso estiver correto - e se fiarmo-nos na leitura de Michel Foucault, que de um certo modo estamos parodiando, poderemos dizer que está - descobriremos o que é que Velázquez está pintando: trata-se do casal real. E, claro, agora faz sentido o porquê da presença da princesinha Margarita no ateliê com suas damas de honra. Descobrimos, também, um outro enigma: o olhar da menina, o da dama à sua esquerda e o da anã, bem como o do cavaleiro ao fundo e o dos serviçais, quase escondidos, dirigem-se todos para o mesmo ponto fora do quadro - o lugar do rei. Mas, como nós, espectadores, podemos assumir o lugar privilegiado que ocupa o rei - de certa maneira somos convidados a isso - somos, por assim dizer, arrebatados de modo a entrar nesse jogo de olhares e identificações.

$\overline{\text { Significação } 14 \cdot 102}$ 
Não escaparam disso, nem poderiam, os leitores célebres de Velázquez, e alguns chegaram a ir bastante longe nesse jogo de representações.

É o propósito deste trabalho examinar a leitura pictural que Picasso fez do quadro de Velázquez, chamando a atenção para alguns aspectos desta leitura, evidenciados pelas marcas, deformações anamorfósicas, que o pintor malaguenho deixou em suas telas.

Não seria nada difícil, depois do trabalho de Fabre, que adotou a mesma classificação das telas encontradas no catálogo do Museo Picasso de Barcelona, ater-se à ordem de produção das 58 telas produzidas por Picasso, mas isso não é o mais relevante considerandose o nosso propósito de apenas chamar a atenção para as inversões anamorfósicas - as mais evidentes - que ocorrem em certas telas da série.

Após reproduzir a tela de Velázquez em cinza-azulado e em estilo cubista (Figura 1), o pintor, colocando-se no mesmo lugar em que se situou Felipe IV para ser pintado, olha direto para a princesa Margarita - a menina dos olhos do rei, aquela que, talvez, tenha feito o soberano ficar sentado por horas a fio e, provavelmente, por dias seguidos, enquanto, apesar de o sol brilhar lá fora, alguma nuvem escura pudesse estar se armando no reino. A leitura de Picasso parece insinuar também isso, mas não nos cabe, no corpo deste trabalho, deslindar esse fio isotópico.

Ocupando o lugar do rei, o olho arguto do pintor cubista, ao tentar transcender o olhar penetrante da princesa, foi além do viço das suas bochechas rosadas, desvendou o dourado luminoso dos cabelos, explorou em minúcias o rico vestido e, ao que tudo indica, comoveu-se com a inocência e a altivez coquete da menina, que deveriam encher de orgulho o poderoso pai. O pintor vislumbrou, no entanto, em meio à luminosidade intensa que banhava aquele rosto infantil, uma divisão que, à medida que suas reproduções tornavamse mais esquemáticas, deixava nítidas as diferenças de incidência de luz, já que o rosto da princesinha, na obra matriz de Velázquez, voltava-se ligeiramente para a sua esquerda, movimento sutil que não seguia seu olhar, que se mantinha firme, quase insolente, na 


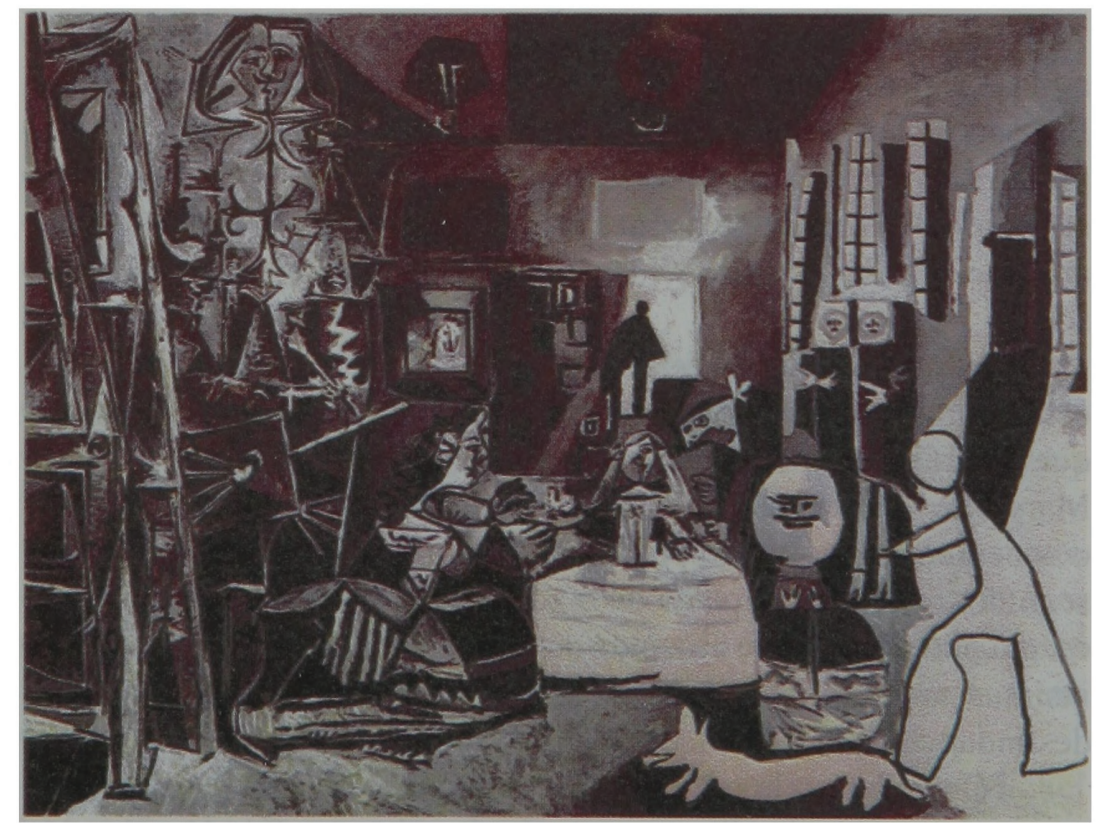

1 - Reprodução de Las meninas feita por Picasso 
direção do rei. Picasso pintou 14 versões exclusivas da infanta, dentre as quais reproduzimos algumas (Figuras 2, 4, 5, 8, 9).

Depois, seu olhar se desloca ligeiramente para a esquerda do quadro, e encontra a dama de honor María Agustina Sarmiento (Figura 3), que oferece, enlevada, numa pequena bandeja, um enigmático pote de argila para a princesinha. $^{3}$ Em seguida, o pintor se volta ligeiramente para a direita, funde o rosto da princesa com o da dama de honra Isabel de Velasco (Figura 16).

Como que reembreado ao ponto de partida, após explorar o núcleo central do quadro de Velázquez, constituído pela princesa e suas damas de companhia, o olhar de Picasso inicia um novo percurso, e vai além dos limites do quadro do mestre, atravessando a porta lá do fundo, para ganhar o espaço exterior. Desvenda, então, um dia luminoso, que o quadro de Velázquez apenas insinuava com a luz que adentrava o ateliê; mas revela, também, um insuspeitado mar azul (Figura 18). As telas sobre o exterior (nove ao todo) compõem uma série dentro da série (Pigeons), e sua seqüência lembra um travelling cinematográfico, como se o olhar do pintor fosse se dirigindo para porta. Isso se evidencia já na primeira tela da série, na qual podemos identificar vestígios do ateliê, na borda esquerda e na parte inferior do quadro. Mas o que há aí? Pássaros brancos, como em nichos, à esquerda. Comparando com o quadro matriz de Velázquez, notamos que nessa mesma posição ficava a parte posterior da tela que ele pintava e da qual só podíamos ver os caixilhos. E, incrível, é nestes vãos - deformados, mas reconhecíveis ao olhar atento - que Picasso alojou, como em ninhos, os seus pássaros. Outros pássaros encontram-se empoleirados num gradil (Figura 19), que agora podemos identificar com alguma facilidade como uma metamorfose da porta ao fundo do quadro de Velázquez, composta por "almofadas" retangulares e em baixo-relevo. Mas se tudo é assim tão motivado neste "delírio", de onde surgiu este mar? Sabemos,

3. Peñuela Cañizal (1993), em seu artigo "A metáfora da intertextualidade" revela aonde pode nos levar a leitura de Picasso a respeito deste gesto singular. 

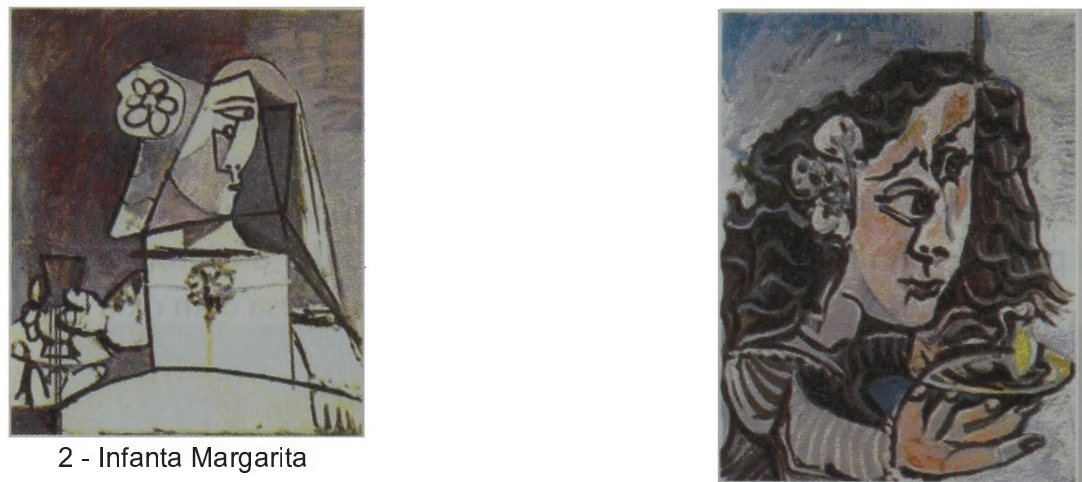

3 - María Agustina Sarmiento
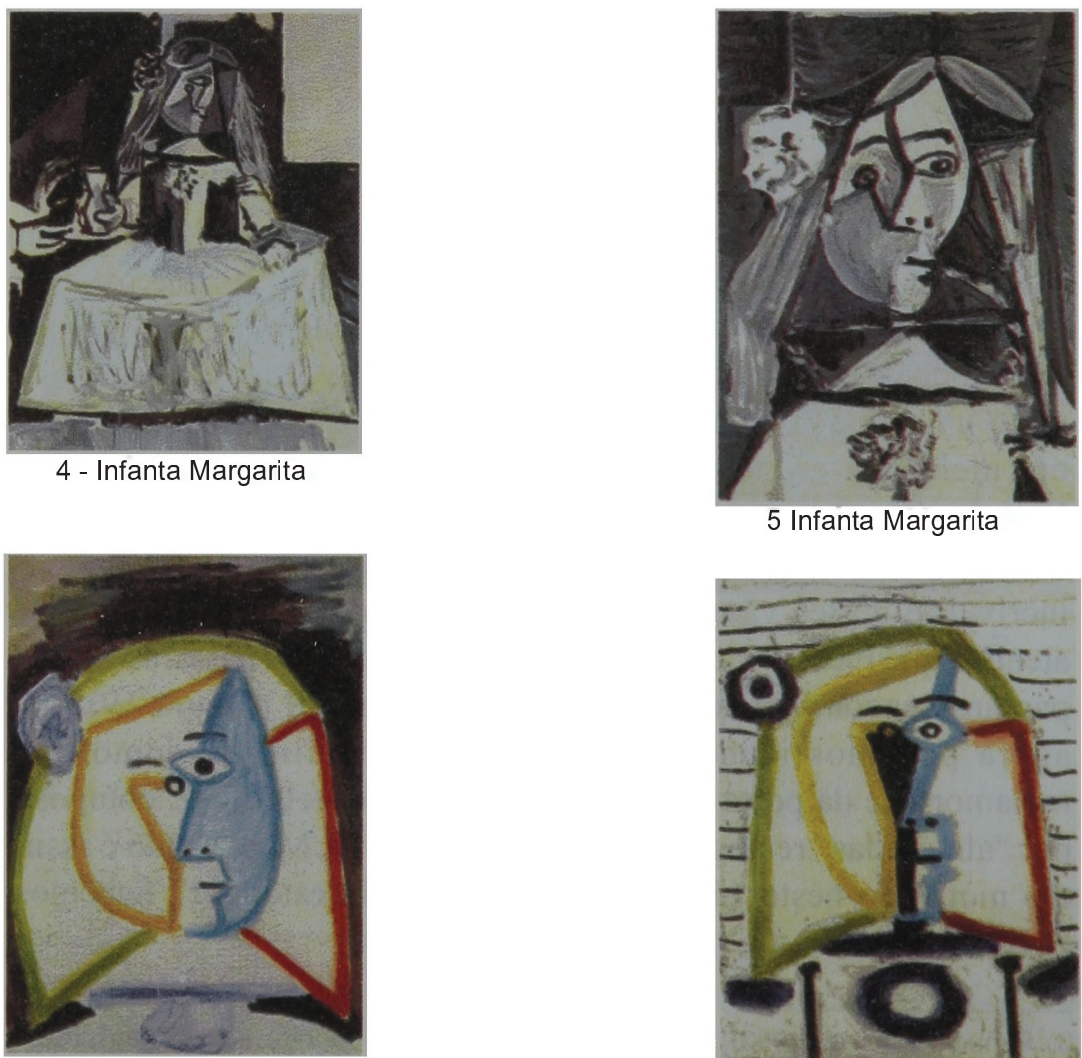

5 Infanta Margarita

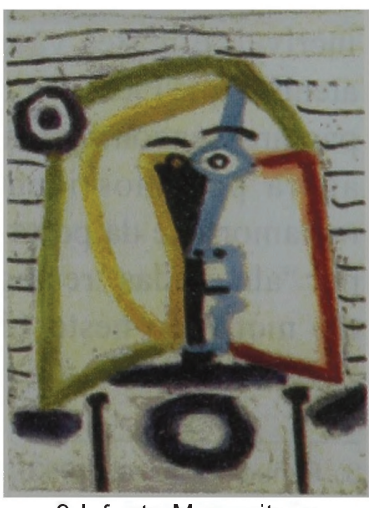

9 Infanta Margarita

Significação 14 • 106 

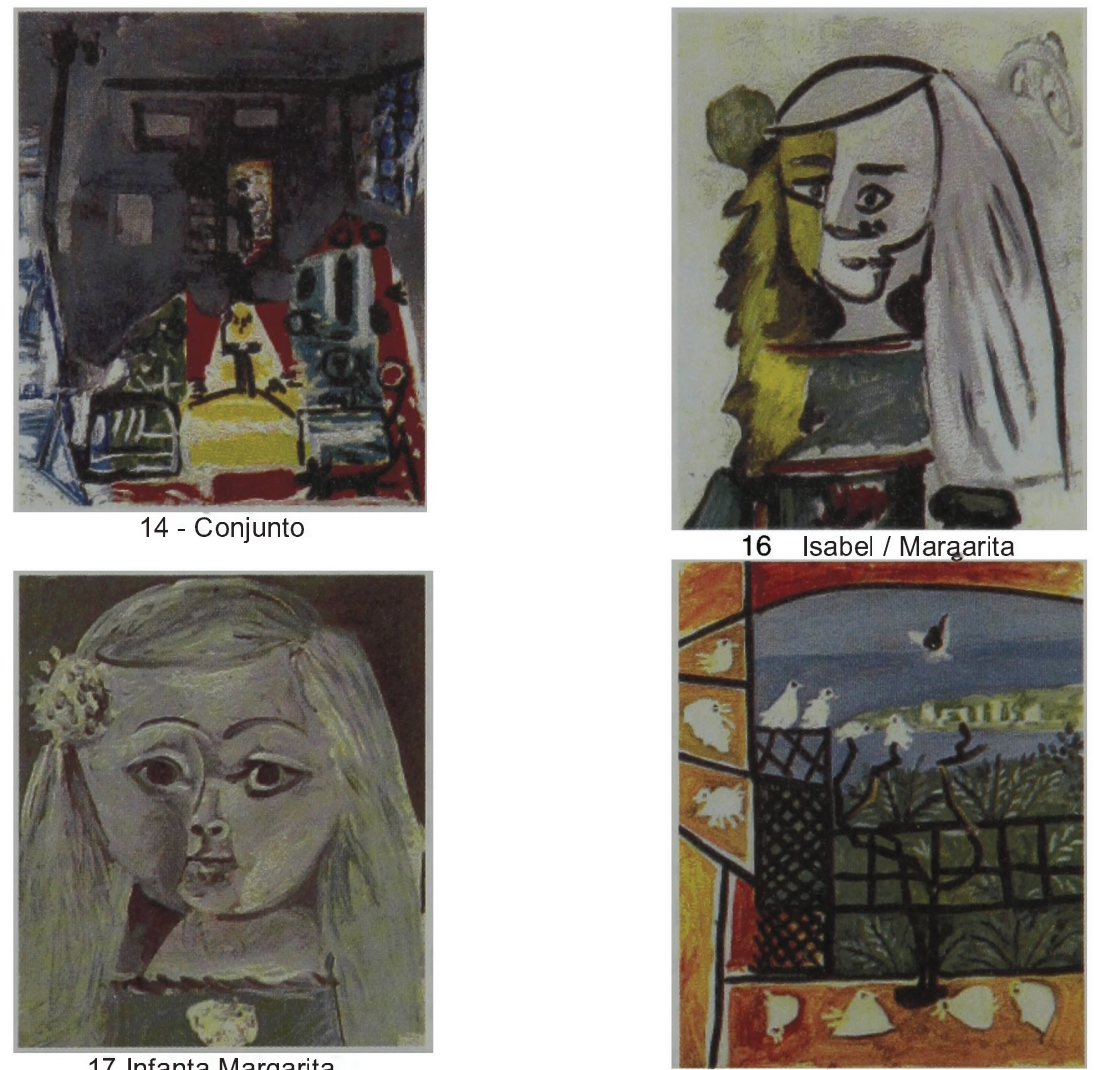

17 Infanta Margarita

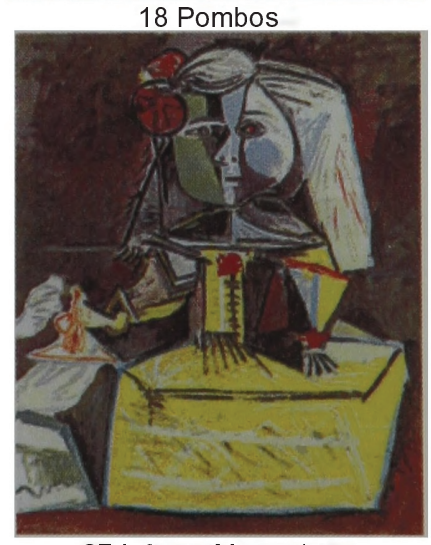

27 Infanta Margarita

$\overline{\text { Significação } 14 \cdot 107}$ 
graças ao estudo de Pierre Daix, La vie de peintre de Pablo Picasso, que o pintor refugiou-se em seu ateliê Californie, em Cannes, para realizar esse trabalho. E a paisagem que vemos bem poderia ser a baía de Cannes. Se é assim, Picasso condensa, nessa série dentro da série, imagens do quadro de Velázquez com imagens que ele vê ao seu redor enquanto trabalha.

Picasso volta à princesinha (Figura 27), depois do "delírio" dos pombos. Pinta, a seguir, um conjunto (Figura 28) em que representa todo o lado direito do quadro de Velázquez, enfatizando as janelas laterais que são quase imperceptíveis na tela matriz. María Agustina, incluída neste conjunto, aparece com a cabeça em formato triangular e estranhamente invertida em relação ao corpo, e o quadro do rei, na parede ao fundo, em destaque, está tão transformado que quase não se distinguem as figuras. Numa outra tomada (o processo parece mesmo cinematográfico), o pintor destaca María Agustina com sua cabeça invertida (Figura 29). Na tela seguinte (Figura 30), podemos perceber que esta cabeça enorme (compare-se com a cabecinha da princesinha nesta mesma tela) é uma espécie de espelhamento do espelho, e que o rosto reproduzido não é, pelo menos não é só, o de María Agustina, mas também o do rei.

No quadro que se segue (Figura 31), sempre considerando a cronologia de produção, o pintor volta a pintar uma vista do conjunto do ateliê, agora todo repartido em cacos como se a tela, de repente, se fragmentasse; dois deles, mais evidenciados, compõem triângulos justapostos que formam um retângulo bicolor: um branco, outro preto. Este último capta, por assim dizer, a cabeça, agora em tamanho e posição normais, de María Agustina. Nesse ponto, fica evidente que o pintor vem trabalhando, desde que saiu da série Pigeons, com o espelho e o trata como um personagem da tela matriz. As telas subseqüentes (Figuras 32,33 e 34) ganham característicasnitidamente cubísticas, e o pintor passa como que a fazer um estudo em que explora cores, formas e linhas, como se tivesse penetrado no "mundo do espelho", que, ao se difractar, refletisse diferentes incidências de luz. Ou seja, tudo se passa como se houvesse uma oscilação do ponto de vista em que se contempla o ateliê - no quadro de Velázquez, este 


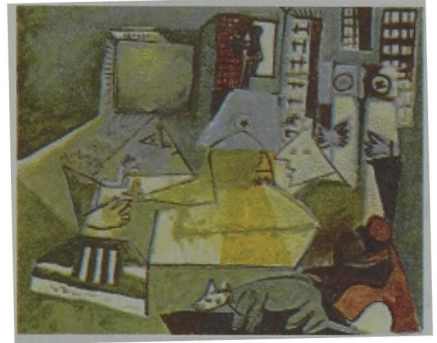

28 Conjunto

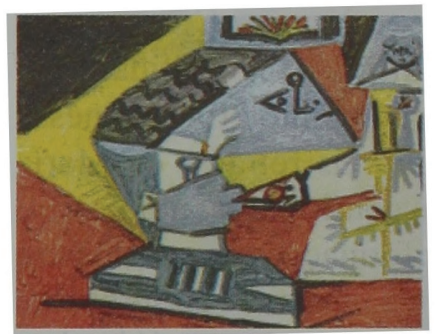

29 - María Agustina e Infanta
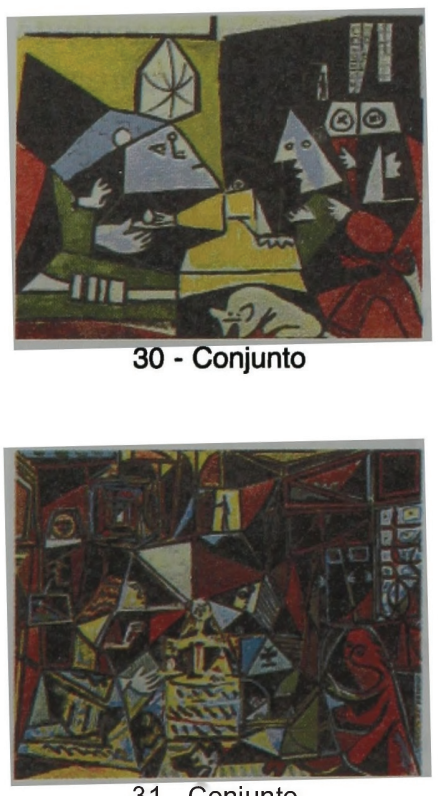

31 - Conjunto
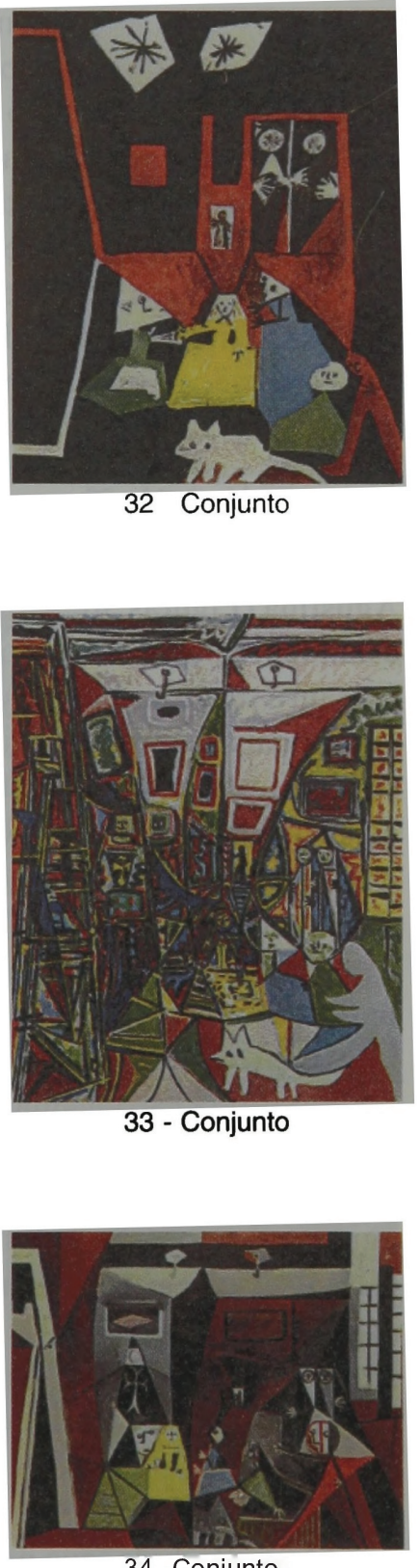

34 -Conjunto

Significação 14 • 109 
ponto é fixo e nele incidem, como ressalta Foucault (1966), o olhar do objeto que está sendo pintado (o rei), o olhar do pintor (o "real", isto é, o não representado na tela) e o olhar do espectador - e essa oscilação fizesse variar nas telas de Picasso os reflexos do espelho, que, por esse motivo, capta imagens e fontes de luz diferenciadas.

Pinta, a seguir, um estranho retrato de Isabel (Figura 35). Na extremidade do cabelo da menina, insere-se uma sombra, cujo contorno lembra o perfil do próprio pintor. Trata-se de uma solução que, segundo nosso conhecimento, é inédita na obra de Picasso, embora Salvador Dalí já a tivesse usado em seu Narciso. Coincidência ou não, a partir daí as telas de Picasso se afastam mais nitidamente do quadro matriz de Velázquez, como se o pintor tivesse nesse momento reconquistado seu estilo cubista. Os retratos de Maria Agustina (Figuras 36, 37, 38, 39), parecem confirmar tal hipótese. E é também a partir deste momento que as deformações anamorfósicas passam a se intensificar e se caracterizar como marcas de perturbações emocionais que se evidenciam nas telas - essas perturbações já haviam se manifestado no que denominamos "delírio dos pombos"; mas aí elas eram provocadas por elementos que se encontravam no contexto enunciativo do pintor; agora, as perturbações parecem decorrer de sentimentos pessoais.

Repare-se na mão esquerda da María Agustina nas telas indicadas: elas são exageradamente grandes. Que sentido atribuir a isso, mero capricho do pintor? Talvez. Na tela seguinte (Figura 40), porém, o processo anamorfósico se intensifica e se manifesta com toda força numa imagem inconfundivelmente onírica. Nicolasico Pertusato, o menino da tela de Velázquez, surpreendentemente agigantado, aparece dedilhando um misterioso piano. O instrumento é escuro, quase negro, mas deixa entrever alguns tons de azulacinzentado e marinho. De onde Picasso tirou essa idéia? Puro delírio? Nem tanto. No quadro matriz, as mãos do menino voam no ar, e não é difícil imaginar que parecem dedilhar algo invisível. Mas, e o piano, de onde teria saído?

Se repararmos bem, o piano se encontra exatamente no lugar da anã María Bárbola, que no quadro de Velázquez é a única a envergar

Significação $14 \cdot 110$ 


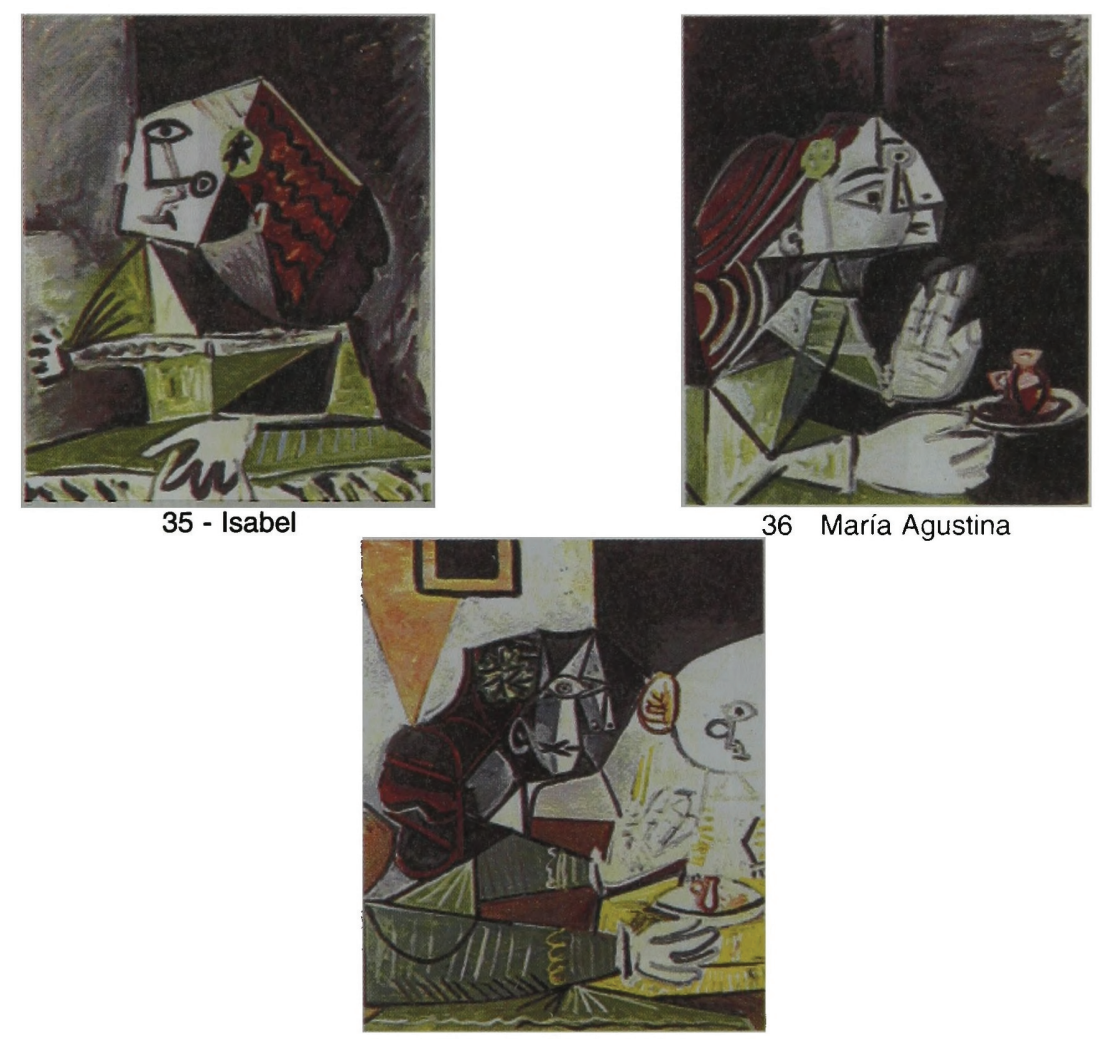

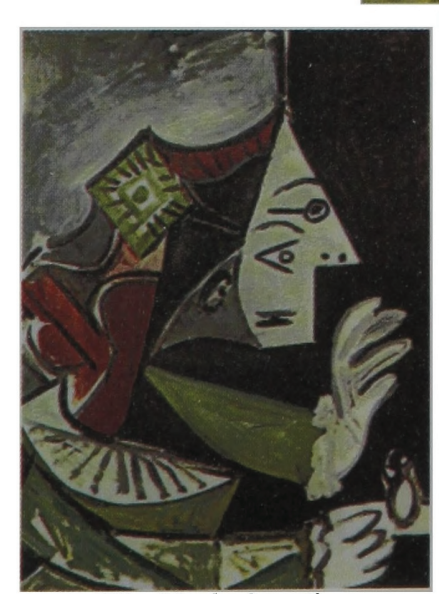

38 - María Agustina

37 María Agustina

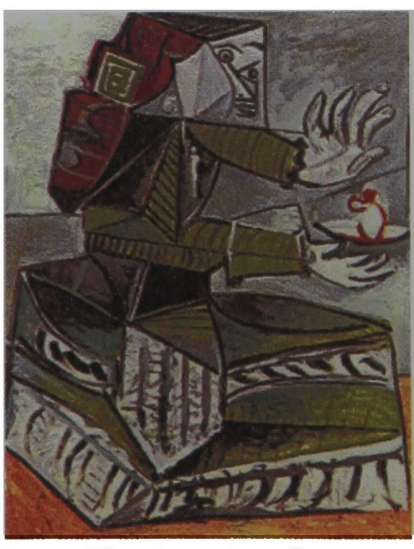

39 María Agustina

$\overline{\text { Significagáo } 14 \cdot 111}$ 


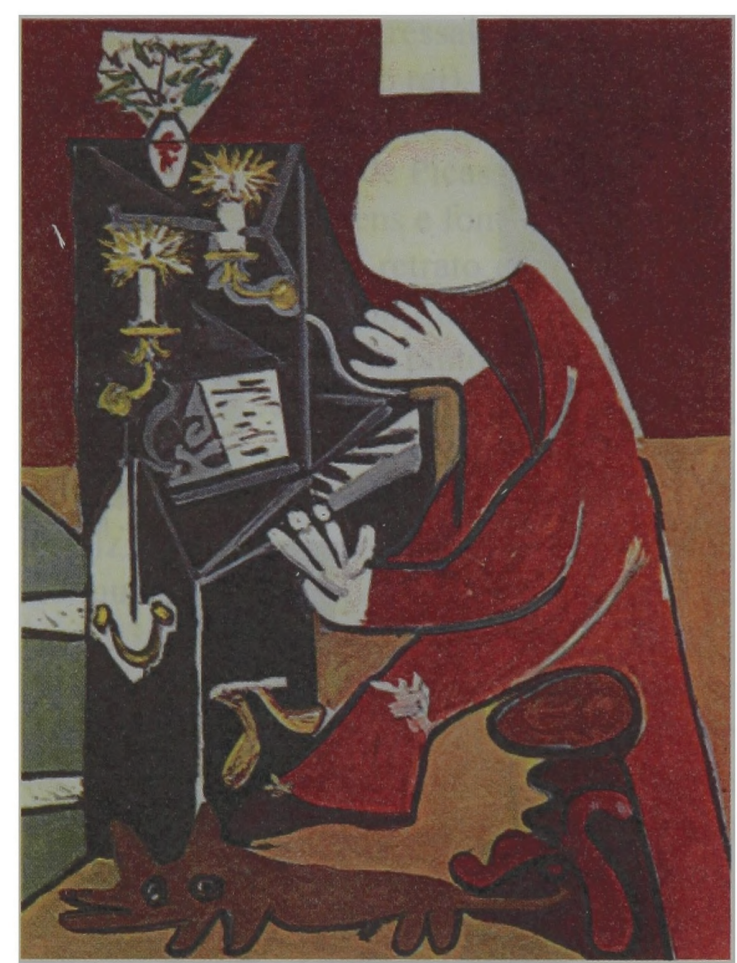

40 - Nicolasico Pertusato / Piano

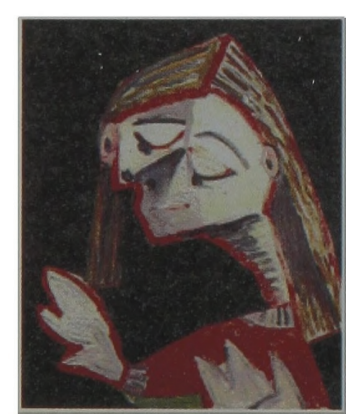

41 Nicolasico Pertusato

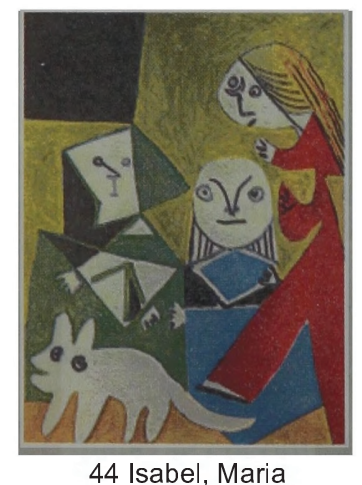

Bárbola e Nicolasico

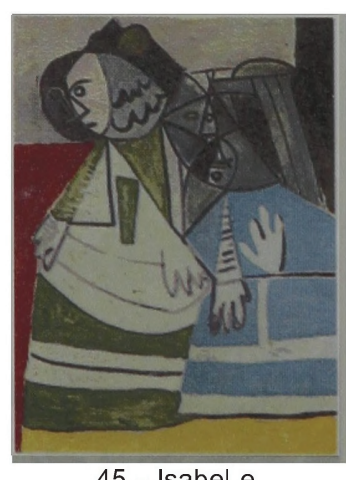
45 - Isabel e
Maria Bárbola 
um vestido azul-escuro com babados brancos, e a mão direita do menino parece tocá-la. E, não bastasse isso, o piano tem um sentido mais vertical do que horizontal, não muito diferente do corpo de María Bárbola, e conta com duas velas acesas na altura em que na figura humana ficariam os seios. Sem falar que a anã, até então não representada nas telas de Picasso, começará a aparecer logo a seguir, depois de urna tela (Figura 41) que apresenta em detalhe o rosto do menino, que traz, como se fosse sua identificação, as duas mãos para cima.

Entre as telas em que figura María, destacamos a Figura 45, onde ela aparece ao lado de Isabel de Velasco, envergando um vestido azul, no qual se destaca um pormenor bastante revelador: seu braço direito (do esquerdo só aparece a mão espalmada) é representado como uma faixa listrada, que reconstitui, para nós de modo inequívoco, as peças alvinegras de um teclado de piano. ${ }^{4}$

Voltando agora para a tela do menino tocando (Figura 40), essas mãos, que voam sobre o teclado leitoso do piano, não lembram pássaros - as famosas pombas de Picasso?

E, identificado isso, passamos a notar que o pintor já vinha brincando com essas anamorfoses há algum tempo. Umas mais outras menos, as mãos de María Agustina da série especular-cubista (Figuras 36, 37, 38 e 39) encontram-se em destaque que lembram asas de pombos. E, incrível, Picasso parece não ter exagerado em demasia; no quadro de Velázquez (Figura I), agora podemos perceber, as mãos de todos os personagens são cuidadosamente destacadas. A série Pigeons, convém lembrar, já havia revelado que os pombos também estavam presentes em Cannes.

Nas Figuras 44 e 45, Picasso junta Maria Bárbola com Isabel de Velasco; depois, na tela seguinte (Figura 46), desloca o ponto de vista mais para a esquerda e focaliza Isabel com a princesinha, de

4. Este piano também pode ser visto como uma referência explícita ao já citado Ballets Russes, e esse sentido polissêmico não exclui, acreditamos, a interpretação que fizemos. 


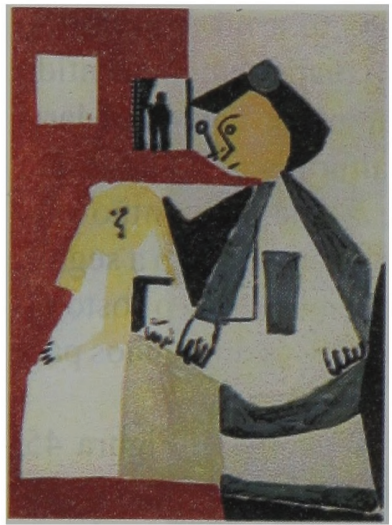

46 - Espelho Branco

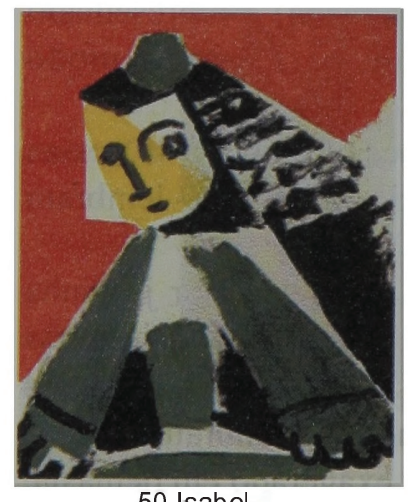

50 Isabel

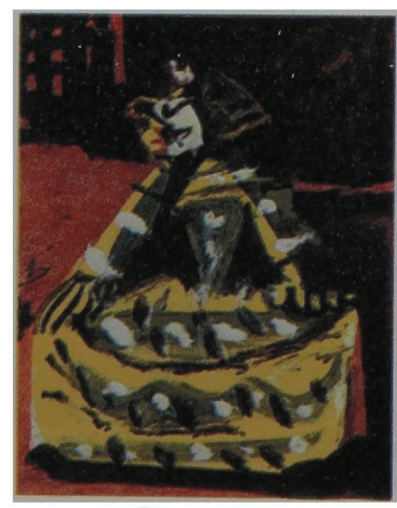

52 Isabel

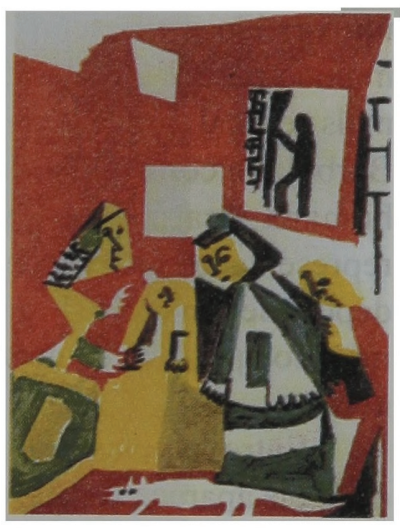

47 - Conjunto / Espelho Branco

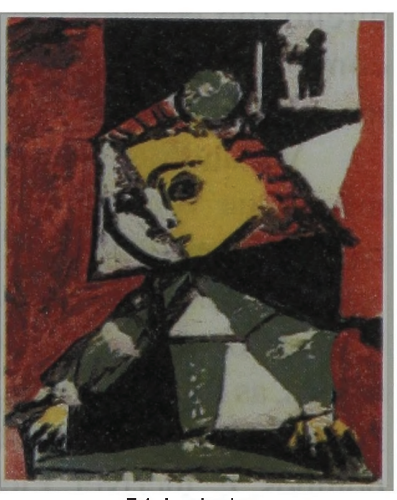

51 Isabel

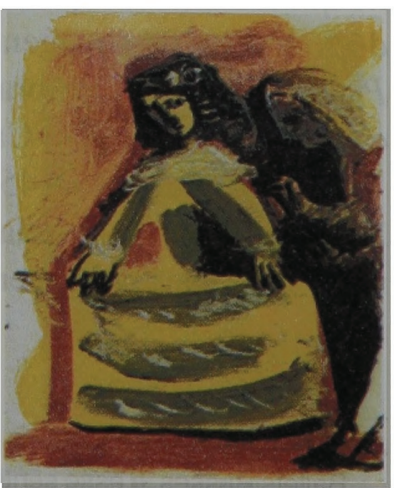

53 - Isabel

Significação $14 \quad 114$ 
modo que se pode ver o fundo do ateliê, com o espelho e a porta representados, esquemáticamente, como um quadrado e um retângulo, brancos. O espelho, representado como pura luz, nada reflete, e parece marcar o fim do que poderíamos chamar "viagem pelo interior do espelho" ou, talvez melhor, "ensaio sobre a visão especular"

A seguir, Picasso fíxa-se em Isabel de Velasco (Figuras 50, 51, 52, 53), que a cada reprodução perde características cubísticas e vai recebendo contornos mais realistas e vestidos suntuosos, como se o pintor estivesse retomando, após uma viagem em que deixara fluir livremente seus devaneios, ao quadro de Velázquez. Ou estaria, ao contrário, tentando fugir inconscientemente de alguma coisa vislumbrada além de seu desejo? O fato é que, como se obedecesse a um impulso interior, Picasso interrompe abruptamente esta última seqüência para registrar, se assim podemos dizer, o que se passa lá fora.

Pinta, então, três paisagens. Nelas, o aspecto outonal é evidente; em nada lembram as paisagens ensolaradas da série Pigeons, nem os fragmentos cubísticos da fase do espelho. De uma tela para outra a desolação é crescente. Na primeira (Figura 54), ainda a luz é forte e se distinguem tons de amarelo; na segunda (Figura 55), há predomínio de um frio azul e venta com mais intensidade; na terceira (Figura 56), as formas da vegetação se confundem, agitadas por um gélido vendaval, que anuncia o inverno. Esses três quadros foram pintados no mesmo dia (2 de dezembro de 1957), o que nos leva a crer que o naturalismo sugerido por essas figuras também está "contaminado" por fortes emoções.

Como que para afastar tamanha desolação, Picasso, levado ao que tudo indica por um outro impulso, abandona o tema de Las meninas, e faz um retrato de Jacqueline (Figura 57), a misteriosa madame Z, que ele apresentara em 1954, e por quem ainda se encontrava emocionalmente envolvido. ${ }^{5} \mathrm{O}$ quadro apresenta, apesar

5. Pouco depois, Jacqueline viria a se casar com Picasso, tornando-se a última de suas esposas.

Significação $14 \cdot 115$ 
Geraldo Carlos do Nascimento

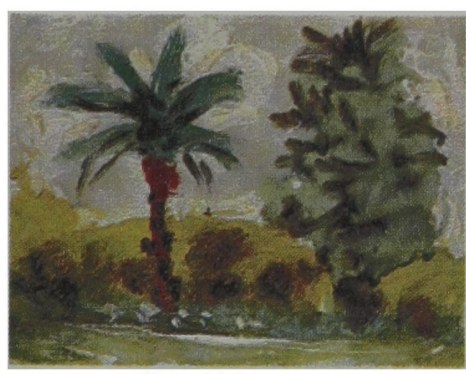

54 Paisagem

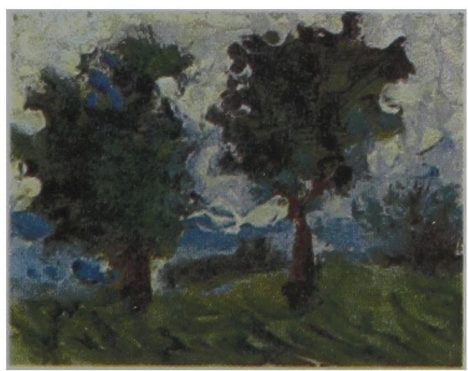

55 Paisagem

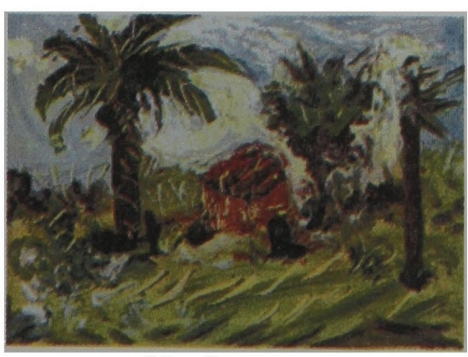

56 - Paisagem

$\overline{\text { Significação } 14 \cdot 116}$

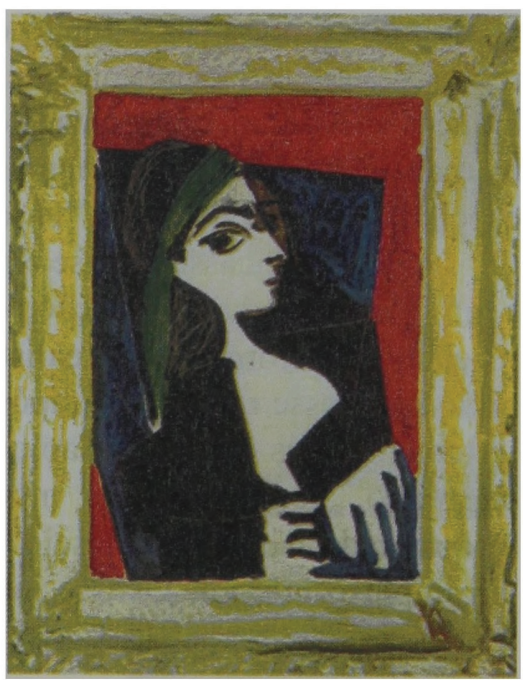

57 - Jacqueline

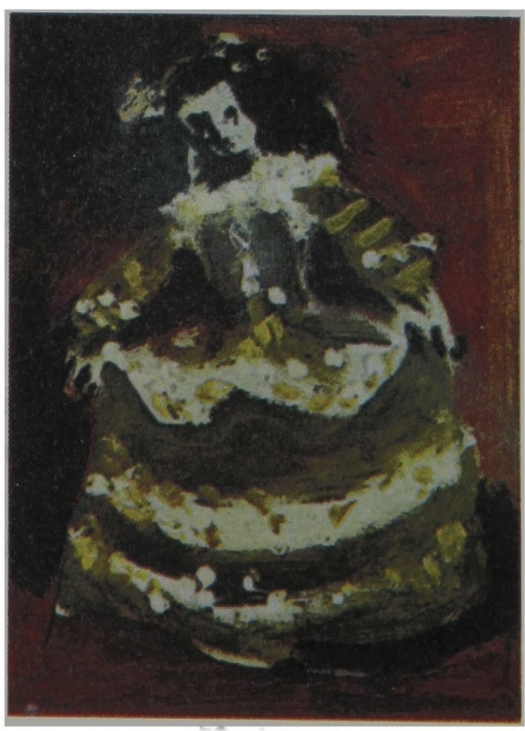

58 Isabel 
de romper temáticamente com a série, algumas de suas características gerais: as formas são simples, as cores são puras, e as mãos de Jacqueline lembram as das personagens que Picasso criou inspirado na tela de Velázquez. O segredo deste quadro residiria nos cabelos da modelo, que, para Fabre (1982), lembram os fios de Ariadne. Mas um estranho e pouco perceptível vulto escuro encontra-se por trás da moça e parece envolvê-la num abraço.

$\mathrm{Na}$ última tela (Figura 58) de Las meninas, Picasso retorna, não como era de se esperar, à princesinha, seu objeto principal de estudo, mas a Isabel, de quem, por sinal, já vinha destacando o belo vestido, em poses que lembram a da princesa. O vestido de Isabel, em verdemusgo e amarelo nas últimas reproduções, justapõe as cores, que podem ser identificadas no quadro de Velázquez: as do vestido da dama, no qual predomina o verde, e as do vestido da princesa, em que predomina o cinza com reflexos dourados. Parece-nos evidente, embora não seja explícito, que Picasso condensa a figura da dama com a da princesa; condensação, aliás, que já se insinuara desde a primeira vez que o pintor retratou Isabel (Figura 16). Mas as semelhanças da indumentária e da pose, enfatizadas demais na análise, não são assim tão logo perceptíveis ao olhar desatento e ficam como que neutralizadas pelos cabelos negros de Isabel. Além disso, uma lágrima escura parece brotar dos olhos da dama, que, imensamente tristes, nem de longe lembram o olhar jubiloso e determinado da princesinha, embora uma tristeza como essa pudesse estar latente na parte escura de seu rosto.

Uma possível explicação para o destaque que Picasso dá a Isabel é preciso lembrar que o pintor inseriu uma sombra que lembra seu próprio perfil num dos retratos da moça (Figura 35) - e a outras deformações anamorfósicas em relação ao quadro matriz decorreriam de um dado biográfico detectado por Fabre: em 1917, o Ballets Russes excursionou pela Espanha apresentando a peça Las meninas, inspirada na obra de Velázquez. Uma das bailarinas do grupo, que provavelmente representava Isabel, era Olga Koklova, que no ano seguinte se casaria com Picasso. Fabre também acredita que as cores das indumentárias utilizadas na peça tenham influenciado Picasso, 
que teria optado por cores bem mais vivas ao invés de adotar o cromatismo do quadro de Velázquez.

Nossa hipótese é de que Picasso, ao se deparar com o quadro do mestre, ocupou o lugar do espectador e sofreu uma espécie de esquize (Lacan, 1988), que acreditamos inerente a todo processo de leitura, $\mathrm{e}$ isso o teria levado aos delizamentos $\mathrm{e}$, mais radicalmente, às anamorfoses - responsáveis pela inversão da perspectiva, pela inversão dos olhares, pela inversão das posições do olhante e do olhado. Las meninas de Velázquez tomam-se assim Las meninas de Picasso.

\section{Bibliografia}

DA1X, Pierre. La vie depeintre de Pablo Picasso. Paris: Seuil, 1978.

FABRE, Josep Palau i. El secreto de Las meninas de Picasso.

Barcelona: Polígrafa, 1982.

FOUCAULT, Michel. As palavras e as coisas. Lisboa: Portugália, 1966.

FREITAS, Jeanne Marie M. Comunicação epsicanálise. São Paulo: Escuta, 1992.

FREUD, Sigmund. Psicologia de massas e análise do eu. In: Obras completas -Tomo III. Madrid: Biblioteca Nova, 1981

LACAN, Jacques. Os escritos técnicos de Freud - Livro I. In: $O$ seminário. Rio de Janeiro: Zahar, 1986.

. Os quatro conceitos fundamentais da psicanálise - Livro

11. In: O seminário. Rio de Janeiro: Zahar, 1988.

A ética e a psicanálise- Livro 7. In: O seminário. Rio de Janeiro: Zahar, 1991.

PEÑUELA CAÑIZAL, Eduardo. A metáfora da intertextual idade. In: BARBOSA, A. M. et al (orgs.). Ensino das artes na universidade. São Paulo: Edusp/CNPq, 1993.

RODRIGUEZ-AGUILERA, C. Picasso de Barcelone. Paris: Circle D'Art, s.d.

Significação $14 \cdot 118$ 